\title{
Improving alcohol screening and brief intervention delivery in general practices
}

Citation for published version (APA):

Abidi, L. (2018). Improving alcohol screening and brief intervention delivery in general practices: an investigation of current practice, barriers and solutions. [Doctoral Thesis, Maastricht University]. Datawyse / Universitaire Pers Maastricht. https://doi.org/10.26481/dis.20181010la

Document status and date:

Published: 01/01/2018

DOI:

10.26481/dis.20181010la

Document Version:

Publisher's PDF, also known as Version of record

\section{Please check the document version of this publication:}

- A submitted manuscript is the version of the article upon submission and before peer-review. There can be important differences between the submitted version and the official published version of record.

People interested in the research are advised to contact the author for the final version of the publication, or visit the DOI to the publisher's website.

- The final author version and the galley proof are versions of the publication after peer review.

- The final published version features the final layout of the paper including the volume, issue and page numbers.

Link to publication

\footnotetext{
General rights rights.

- You may freely distribute the URL identifying the publication in the public portal. please follow below link for the End User Agreement:

www.umlib.nl/taverne-license

Take down policy

If you believe that this document breaches copyright please contact us at:

repository@maastrichtuniversity.nl

providing details and we will investigate your claim.
}

Copyright and moral rights for the publications made accessible in the public portal are retained by the authors and/or other copyright owners and it is a condition of accessing publications that users recognise and abide by the legal requirements associated with these

- Users may download and print one copy of any publication from the public portal for the purpose of private study or research.

- You may not further distribute the material or use it for any profit-making activity or commercial gain

If the publication is distributed under the terms of Article $25 \mathrm{fa}$ of the Dutch Copyright Act, indicated by the "Taverne" license above, 
Valorisation Addendum 


\section{Relevance}

Alcohol is an important risk factor for illness, disability, and mortality (Rehm et al., 2009). The detrimental impact of alcohol on the global burden of disease is considerable (Rehm et al., 2012; WHO, 2014). Additionally, alcohol consumption also contributes to social harm such as vandalism, aggression, domestic violence, criminality, workrelated losses of productivity, crimes and traffic violations (Schrijvers, Snoek, \& van den Ende, 2010)., leading to higher overall cost associated with alcohol use (Rehm et al, 2009). The social harm related to alcohol use, makes alcohol a commodity that has relevance for many fields. Previous studies have shown that alcohol screening and brief intervention (ASBI) delivery in primary care is one of the highest-ranking effective services evaluated and is also cost-saving from the societal perspective (Solberg et al., 2008; Angus, Latimer, Preston, Li, \& Purshouse, 2014; Kaner et al., 2018). Alcohol screening and brief intervention delivery is therefore important and relevant in terms of preventing health consequences as well as the societal impact and costs of excessive and problematic alcohol use.

Primary care, and in particular general practices, has enormous potential to improve population health. A previous study in England that investigated the cost-effectiveness and resourcing implications of ASBI has shown that screening patients on registration with a GP would capture approximately $40 \%$ of the population over a 10 -year period, and screening patients at next primary care consultation would capture $96 \%$ of the population over a 10-year period (Purshouse et al., 2013). This means that implementation of ASBI in general practices can reach a large part of the population and can therefore curb alcohol's impact on society. Yet, in current practice, this potential is far from being achieved (Johnson, Jackson, Guillaume, Meier \& Goyder, 2010) and efforts to improve ASBI implementation are urgently needed. The findings of this thesis are highly relevant to advance this field. As previous implementation efforts have proven to be difficult, a new implementation program was developed in order to examine its effectiveness on GPs' ASBI delivery behavior. Results of the development and evaluation of the program have relevance for public health care. Effective interventions can reach their full potential and impact public health only when the intervention is embedded successfully in health care settings. Therefore, ASBI implementation studies are important to get insight into what works and what doesn't work, and also what is further needed inside and outside public health settings in order to reach successful ASBI implementation.

The knowledge generated in this thesis is highly relevant for GP practices, education and policy makers as it shows that there is a lack of attention for the subject of alcohol use in general practices and provides insights in solutions to solving barriers to ASBI implementation in general practices. 


\section{Target groups}

The findings presented in this thesis are relevant for GPs, patients and educators. For GPs, this thesis provides insight into the underregistration of problematic alcohol use in medical records, what difficulties GPs experience in addressing alcohol use and about how the barriers can be tackled. It provides information about which tool to use to screen patients and a description of an implementation program. For patients, it can be important and relevant to know that GPs find it very difficult to discuss the topic of alcohol use. For example patient organizations that represent the interests of persons affected by mental illness can use the information in this thesis to inform their members about alcohol use. General practices can also use the generated knowledge in this thesis to improve information provision to patients visiting their GP.

Furthermore, the findings in this thesis are also relevant for organizations such as the Dutch College of General Practitioners, which is the scientific society of Dutch general practitioners (GPs) and aims to improve and to support evidence-based general practice. The Dutch College of General Practitioners also issues guidelines on detection and treatment of problematic alcohol use. The results may also be of interest to organizations that develop medical support tools or organizations that provide and develop trainings and educational programs for GPs, such as certified training organizations or universities. These organizations aim to translate scientific knowledge and experience to trainings and educational programs that are focused on clinical practice. Trainings and educational programs may for instance focus on improving current practice regarding registration of alcohol abuse diagnoses in medical records in order to improve monitoring of health parameters and quality of care. Furthermore, it is equally important to train GPs to recognize those symptoms that are related to excessive or problematic alcohol use, as recommended by the Dutch Guidelines for General Practitioners (Boomsma et al., 2014).

The results may also be of interest to organizations involved in the development of ASBI implementation programs. Developers of an ASBI implementation program may be interested in developing a program by using the input that was provided by alcohol prevention experts as well as GPs and practice nurses in the Delphi study reported in this thesis. GPs, practice nurses as well as alcohol prevention experts have for instance recommended clear guidelines, service provision of addiction care centers, improving communication between addiction care centers and general practices, shortening of waiting lists and more publicity in the media to create awareness about problematic alcohol use. These ideas were consensually listed as solutions to barriers of ASBI, and can therefore at least be considered as possible components or areas of focus in future implementation programs. The findings of this thesis might also be interesting to municipalities, governmental organizations or health care organizations outside primary health care settings as it is apparently difficult to implement ASBI in general practice settings and reach the desired public health impact. For example, the national govern- 
ment as well as local governments could develop regulations/policies outside health care settings that help bring more attention to excessive and problematic alcohol use. For instance, policies covering marketing restrictions and taxation of alcohol have been proven to be effective in reducing population levels of alcohol consumption.

Lastly, the findings presented in this thesis are relevant for scientific researchers as they provide relevant starting points to further investigate implementation of alcohol screening and brief intervention delivery and to optimize studies in general practices.

\section{Products and Activities}

The knowledge obtained from the results in this thesis can be used in many ways. The obtained knowledge is in that sense a product as it can be used to update guidelines and make recommendations to stakeholders from various organizations (e.g. preventative health care, primary or secondary health care organizations), or local policymakers in city councils. The knowledge generated in this thesis can be used to increase attention in the (post)graduate training of medical doctors to the problem of underregistration of alcohol abuse diagnoses in medical records. The knowledge obtained in this thesis can also be used in workshops or trainings to update health professionals' knowledge about patients' attitudes regarding health professionals addressing alcohol use in consultations.

The main product developed in this thesis was the ASBI implementation program. We used a stepwise method to develop the ASBI implementation program, in which important underlying determinants and solutions were identified and theoreticallysound intervention techniques were selected. The program components have been developed in line with preferences and feasibility ratings of GPs reported in the Delphi study. The implementation program consisted of three components: (1) an e-learning module that targets barriers related to knowledge and skills; (2) an online tailored feedback module that targets barriers related to attitude and motivation, and (3) a website to access support and materials such as screening questionnaires, a website and contact information of addiction prevention workers. The e-learning component is freely available online and can be accessed by any GP that wants to follow the e-learning module. The other components are not readily accessible, but could be made available if needed. However, in the published protocol paper, an overview is provided of the information, methods and applications used in these components that can be added in other trainings or educational programs.

Furthermore, the publication of Chapter 2 of this thesis was accompanied by a press release from Maastricht University. In this press release, the results of our study were presented showing that $11.1 \%$ of the total patient sample in the study screened positive on an alcohol use disorder, of which a strikingly low number of patients were registered 
by their GP. The press release was noticed by various media outlets throughout the Netherlands, and they reported about this study in their news articles.

The results of this thesis were presented in various national and international scientific conferences that had themes about translating scientific knowledge to practice. Presentations were given at the Forum Alcohol and Drugs Research (FADO), the European Health Society Conference, the Kettil Bruun Society (KBS) for Social and Epidemiological Research on Alcohol and the Nordic Implementation Conference. In addition, results of these studies were incorporated in a presentation delivered by the author of this thesis in an accredited face-to-face training program for GPs about addressing alcohol use in general practice.

\section{Innovation}

The current supply of training programs in the Netherlands primarily focusses on knowledge transfer and attainment of skills regarding ASBI delivery. Our implementation program added focus to an important domain, which can be easily overlooked: the domain of motivation and attitudes of GPs, that included feedback on stigmatizing beliefs, beliefs about their own professional role, beliefs about ASBI efficacy and other important motivational factors. Furthermore, we have linked addiction prevention workers to local GPs in the area and provided contact information of addiction prevention workers to GPs. It is worth to investigate whether this innovation works in practice. The innovative aspect of the implementation program lies in the fact that it was a brief program which was made easily available and accessible to GPs, and that it has clear theoretical underpinnings.

The studies conducted in this thesis build upon a long line of research in the field of ASBI. One particular study in this thesis was innovative in the sense that the study evaluated a recently implemented policy related to the introduction of practice nurses mental health in Dutch general practice settings. Data of practices were collected of a period of time in which some general practices had not implemented practice nurses mental health in their practices yet and could be evaluated as control practices. Another innovative aspect of this thesis was the large population study that was conducted among individuals visiting health care in order to assess patients' attitudes regarding health professionals addressing alcohol use in consultations. 


\section{References}

Angus, C., Latimer, N., Preston, L., Li, J., \& Purshouse, R. (2014). What are the implications for policy makers? A systematic review of the cost-effectiveness of screening and brief interventions for alcohol misuse in primary care. Frontiers in psychiatry, 5, 114.

Boomsma, L. J., Drost, I. M., Larsen, I. M., Luijkx, J. J. H. M., Meerkerk, G. J., Valken, N., Verduijn, M., Burgers, J. S., Van der Weele, G. M., \& Sijbom, M. (2014). NHG-Standaard Problematisch alcoholgebruik (derde herziening). Huisarts Wet, 57(12), 638-46.

Johnson, M., Jackson, R., Guillaume, L., Meier, P., \& Goyder, E. (2010). Barriers and facilitators to implementing screening and brief intervention for alcohol misuse: a systematic review of qualitative evidence. Journal of Public Health, 33(3), 412-421.

Kaner, E. F., Beyer, F. R., Muirhead, C., Campbell, F., Pienaar, E. D., Bertholet, N., ... \& Burnand, B. (2018). Effectiveness of brief alcohol interventions in primary care populations. Cochrane database of systematic reviews, (2).

Purshouse, R. C., Brennan, A., Rafia, R., Latimer, N. R., Archer, R. J., Angus, C. R., Preston, L. R., Meier, P. S. (2013). Modelling the cost-effectiveness of alcohol screening and brief interventions in primary care in England. Alcohol and alcoholism, 48(2), 180-188.

Rehm, J., Shield, K. D., Rehm, M. X., Gmel, G., \& Frick, U. (2012). Alcohol consumption, alcohol dependence and attributable burden of disease in Europe. Centre for Addiction and Mental Health.

Rehm, J., et al., Global burden of disease and injury and economic cost attributable to alcohol use and alcoholuse disorders. The Lancet, 2009. 373 p. 2223-33.

Schrijvers, C., Snoek, A., \& Van den Ende, D. (2010). Preventie van schadelijk alcoholgebruik en drugsgebruik onder volwassenen. IVO, Rotterdam.

Solberg, L. I., Maciosek, M. V., \& Edwards, N. M. (2008). Primary care intervention to reduce alcohol misuse: ranking its health impact and cost effectiveness. American journal of preventive medicine, 34(2), 143152.

World Health Organization, \& World Health Organization. Management of Substance Abuse Unit. (2014). Global status report on alcohol and health, 2014. World Health Organization. 